\title{
Lifestyle and fashion in Mario Camerini's romantic comedies II Signor Max and I Grandi Magazzini
}

\author{
CHIARA FAGGELLA, Stockholm University
}

\begin{abstract}
Between the years 1922 and 1943, Italian Fascism revealed quite an ambivalent attitude towards lifestyle. ${ }^{1}$ While the regime tried to impose standards of nationalistic moderation, popular entertainment of the time reveals that different aspects of culture never surrendered completely to the diktats of the regime. This article discusses the ways in which two films, Il Signor Max (Astra Film, 1937) and I Grandi Magazzini (Amato-Era Film, 1939) can provide a perspective into the consumer culture of Fascist Italy and its ambivalences. By presenting recurrent references to lifestyle commodities and fashion, the experiences of consumption in the two films take center stage in spite of the regime's campaigns for modesty.
\end{abstract}

\section{KEYWORDS}

Fascism, Lifestyle, Fashion, Comedy, Film

\section{Introduction}

One of the main purposes of Fascism was that of molding a completely new population, though characterized by strong roots in the glorious past of Italy and in the peasant traditions of agriculture, the backbone of its economy. Its ideology comprised a general disapproval for everything that looked foreign, sophisticated and elitist. Conversely, popular entertainment of the time reveals a more complicated picture in which different aspects of culture never surrendered completely to the diktats of the regime, displaying a fascination for foreign fashion and leisure goods. Despite its totalitarian blueprint and what some historians have deemed to be a significant political consensus, Fascism lately proved to be unable, and occasionally unwilling, to restrain the desires of the masses and to direct them according to its own objectives (Gentile, 2003). In this regard, Stephen Gundle has proposed to look at Italian cinema during Fascism as one of those areas of cultural production in which the regime's aims of control were either defeated or struggling against the interests of private, commercial players (Gundle 2013). This position contrasts especially with what Emilio Gentile has been asserting on the pervasiveness of Fascism as a political religion, and the supposedly large consent base that it enjoyed thanks to its energetic censorship over media (mainly radio and journalism) (Forgacs and Gundle, 2007).

\footnotetext{
${ }^{1}$ The use of the capital ' $\mathrm{f}$ ' is employed to specifically indicate the totalitarian regime led by Benito Mussolini, which occurred in Italy between the years 1922 and 1943, and to distinguish it from additional national variations (e.g. Spanish Falangism).
} 
During Fascism, then, it is interesting to witness the developments of a series of films that expressed whims and desires for a glamorous lifestyle within the so-called cinema dei telefoni bianchi (white telephones' cinema). This article discusses the ways in which two films, traditionally categorized as belonging to the white telephones genre, can provide a perspective into aspects of consumer culture under Fascism. Far from being subversive, Il Signor Max (Astra Film, 1937) and I Grandi Magazzini (Amato-Era Film, 1939) distinguished themselves among the many theatrical melodramas, foreign-inspired comedies or historical tragedies. Through reasonably realistic representations of contemporary society, their main characters are ordinary men and women from the lower and lower-middle classes, usually salesgirls or delivery men. The two films present recurrent references to lifestyle commodities, particularly to articles of clothing and leisure activities, with which the protagonists related by means of compulsive relationships. Their stories revolved insistently around on the importance of objects and activities, the experiences of consumption take center stage. As consumerism was opposed by the regime, its presence in the two films is an expression of the typical bourgeois individualism that Fascism overtly opposed.

\section{The controversial 'white telephones'}

Traditionally, scholars have regarded Il signor Max and I I Grandi Magazzini as belonging to the 'white telephone' genre (Mida and Quaglietti, 1980; Landy, 1986; Casadio, Laura and Cristiano, 1991). The peculiarity of the genre was the display of a lavish lifestyle, unattainable for the average Italian audience, which often upstaged the storylines. Its development has been ascribed to the comedy of manners and as the Italian take on Hollywood's screwball comedy, influenced by a certain Hungarian situational social comedy (Landy 1986, 121; Moliterno 2008, 340). The name originates from the profuse presence of white telephones in film scenes, as elements of interior design and signifiers for both affluence and distinctiveness: the possibility of making phone calls at home represented an exclusive commodity, accessible only to the wealthier. Moreover, the color white differentiated the domestic phone from the more popular version in black, generally used in offices and work environments. Drawing a parallel with nineteenth century pictorial art, where nudity was accepted only if the setting was visibly classical, scandalous relationships and social difficulties could only be depicted in Italian cinema at that time using remote settings. Foreign countries, among which Hungary was a favorite, were often chosen as fictional locations: Fascist authorities banned racy themes and crimes from being represented as possible occurrences in the apparently neat and ordered Italian society.

Conversely, white telephones have become a synonym for a shameful past of the history of Italian cinema, during which censorship was masked by attention to décor and formulaic content. For this reason, there had long been the opinion that '[...] the aim of these films was that of inhibiting the Italian population from thinking during one of the darkest moment of our country. The [First World W]ar, especially a lost war, ought to be removed from the collective memory; nothing better than escapist cinema, the most frivolous, the most stupid, the most illusory and unreal show[...]' (Casadio, Laura and Cristiano 1991, 9). When a cultural reevaluation of cinema of the Fascist period started in the late 1970s, as suggested by Gundle, scholars began to question the traditional historiography that had dismissed the white telephone genre on the basis that its '[...] narratives 
would seem to merit the disapprobation heaped upon them of being frivolous and inconsequential. On closer inspection, the seemingly trivial characters and situations are an index to familiar bourgeois myths and attitudes' $(2013,121)$.

Prejudice undoubtedly biased research, as scholars hastily grouped countless productions in the white telephones genre, among which there were films indeed extremely dissimilar from one another (Landy 1998, 45). Due to this inclusion, the negative assessments directed towards the initial genre spread over the totality of cinema produced under Fascism, because of both the poor quality of some of the films and the stigma caused by the historical period in which the white telephones were born. Consequentially, the notion that white telephones films ceased to be produced in Italian cinema immediately after 1945 has long been supported since the formal end of Second World War and the establishment of neorealism (Landy 1986, 230). Yet, as argued by film scholar Carlo Celli, it would be quite imprudent to think that techniques, styles and themes adopted by Italian directors in the immediate post-war years were not in any way related to the experiences of their most recent past (2001, 3-17). According to Marcia Landy, '[...] the popular Italian cinema of the Ventennio, especially those feature films described as escapist [...] have much to communicate about fascist culture. Rather than being removed from Italian reality, they are a good indication of how that reality was constructed' $(1986,20)$.

This article discusses the ways in which the work of director Mario Camerini is particularly relevant in this matter, given his films' predisposition to realism and the recurrence of representations of lower and lower-middle classes. During a career spanning nearly forty years, his film activity approached different themes, yet the average settings in several of his films in the 1930s present an interesting representation of Italian society at that time, at least in comparison to other popular commercial films. As the regime required Italian film directors and producers to mitigate the harshness of realism in their representations of life, optimism was to favor in lieu of distrust in society. Since the early 1930s, the general message that the regime wished for every media to convey aimed at '[...] optimism, trust and confidence in the future. Eliminate alarmist, pessimistic, catastrophic and depressing news' (Cannistraro 1975, 420). Yet, while exact directives for press and radio were a standard procedure, the regime did never organize its actions in the same disciplined manner when it came to national cinema. While there was no case of films openly dissident or critical towards the regime, a number of films did not exactly reflect the same cultural principles and ideologies endorsed by Fascism. In this context, Camerini's comedies provided a fertile terrain for realistic representations of society at that time, featuring popular common sense rather than the grand escapism of luxurious settings of the more 'proper' white telephones films.

\section{II signor Max}

Despite his job as newspaper seller, Gianni (Vittorio De Sica), has 'an obsession', as it is said in the movie, for the upper class. Old high school friend Max Varaldo, a wealthy count, offers him a firstclass ticket for a trip aboard a transatlantic liner. Once on board, Gianni is mistaken for his friend Max Varaldo by a group of aristocrats, among which the beautiful Paola (Rubi Dalma) and her younger sister Pucci (Lilia Dale, credited as Adonella) are accompanied by the maid Lauretta (Assia Noris). Thrilled by the lifestyle of his new acquaintances, Gianni decides to continue his charade as 
Max Varaldo with Paola once they are back in Rome. There, as he bumps into Lauretta in his ordinary clothes, Gianni pretends to be courting her in order to obtain information on Paola. After a series of misunderstandings, Gianni will eventually realize that Lauretta is indeed his true love.

In a later interview, director Mario Camerini affirmed that, '[ ...] in contrast to what all the critics believed, those who were saying that it was a satire against the aristocracy, Il signor Max was a satire against the blue collar worker who wants to be a snob.'2 The main character Gianni is torn between what has been decided for him, and what he would actually like to do with his life. After inheriting a newspaper stand from his father, he is forced to abandon high school and start working. His family, ordinary lower-middle class people, would like him to conduct a modest life, instead of vainly admiring the lifestyle of the upper class. Gianni appears concerned only about matters of appearance and is happy when he can pamper himself with small luxuries, such as occasional traveling and elegant clothes, temporarily elevating his ordinary lifestyle.

Unfortunately, even if Gianni tries hard to conceive his humble social status, some aspects of his manners denounce his displacement to the audience. Traveling for the first time in first class aboard a liner, Gianni tries whisky for the first time and casually orders it at the bar, though he does not know any brand nor likes the taste of it. When Gianni explains later that the whisky caused him a stomachache, a friend asks what is whisky and if it is good, to which an embarrassed Gianni replies: 'Well, they [the aristocrats] drink it all the time.' Yet Gianni's most uncomfortable social inadequacy is, probably, his unfamiliarity with the game of bridge. His attempts to play are fiddly, since Gianni does not understand the rules and makes a fool of himself by trying anyway. The role of this card game as a social marker is loaded with great importance in the film, as it marks both the beginning and the end of Gianni's courtship of the aristocratic Paola. At first, aboard the steamship, Gianni is forced to join a group of players, much to his dismay. He is anyway soon relieved from his obligation thanks to another player, who voluntarily offers to take his place. Back in Rome, Gianni takes classes to learn how to play bridge. At the end of the film, he plays his last game and keeps making mistakes, annoying the other players and completely misunderstanding the biddings. Paola, upset with his behavior, asks another guest to take his place, as Gianni is being scolded because 'bridge is not a game for kids.' Gianni's aspirations to a luxurious lifestyle is in opposition to the archetypal frugality advocated by Mussolini, who stated that ' $[\ldots]$ the Fascist man loathes a comfortable life' (Pugliese 2001, 84). In Il Signor Max, the protagonist's representation of masculinity contrasts explicitly with the male Fascist aesthetics, characterized by the exaltation of 'manly' manners and virility. Gianni invests in his outer appearance with continuous splurges of money in apparel and commodities, carefully chosen in order to display an appropriate look.

The most crucial scenes in the development of the plot, for this reason, are those in which Gianni handles elements of clothing, or cultivates his aesthetic inclinations. In the beginning of the film, the 'real' Max Varaldo makes sure that Gianni has a tuxedo, because it is required from first-class passengers. Gianni replies that he brought along both a tuxedo and a tailcoat, showing that he knows exactly the dress code required by such an occasion. Furthermore, Gianni's foreign

\footnotetext{
${ }^{2}$ Mario Camerini quoted in Sergio Gmerk Germani, 'Conversazione con Mario Camerini', Camerini/De Sica (19751978; Rome: Ripley’s Home Video, 2009), DVD.
} 
magazines lead Paola to believe that he indeed is another sophisticated member of the upper class. Finally, when he is invited to go horse riding by Paola and her friends, Gianni asks his friend Peppe to go to a boutique named Eleganza Maschile, 'elegance for men', and to buy him a pair of riding breechs and a pair of riding boots, admonishing him to 'Buy the most beautiful ones, and spend! Spend a lot!' Even if he acts in an environment in which he does not belong, Gianni does not spend money carelessly on random objects, and appears to know exactly what kind of attire and behavior are required in different situations.

Thanks to his job at the newsstand, Gianni is an enthusiastic consumer of magazines, which he faithfully reads in order to be informed on the latest trends suggested to fashionable men, as he reads aloud from a copy of Esquire. Gianni's reliance on magazines becomes thus decisive in securing Paola and her friends' approval. Gianni's only contact with the masculine model of behavior encouraged by the regime concerns his interests in sport, though foreign ones (and not, for example, the supposedly italianissimo soccer which was renamed calcio), and the participation in his uncle's dopolavoro (after work activities) (de Grazia, 1981, 24). To convince Lauretta about the good-heartedness of Gianni, his uncle Pietro tells her that the dopolavoro is the only place where Gianni spends all his spare time, lying shamelessly on his nephew's inclinations.

The rich sisters Paola and Pucci are Camerini's take on the social élites of the time. Mario Camerini recalled later that, when the film was first screened at Venice International Film Festival in 1937, Luigi Freddi was concerned by the fact that members of the aristocracy in attendance that night might be irritated by Camerini's portrayal. ${ }^{3}$ The film, remembered Camerini, was instead a huge success, praised also by those members of Italian aristocracy who attended the screening: 'They understood that the spoof was not directed to them, I pictured them as they actually are, but the spoof was directed to the worker who wanted to be a signore. ${ }^{\text {'4 }}$ In particular, Paola appears as international and sophisticated as actual members of the upper class would, when photographed in society magazines of the time. She is pictured wearing dramatic outfits, veiled hats and furs, as in her first scene with Gianni aboard the ship and their encounter at the Grand Hotel. It is quite interesting to investigate the character of Pucci, a thirteen year old girl, whose wealth allows her to experience the world. She spends time in fashionable venues, stays up late during parties, travels around the world and already has a personal assistant, Lauretta. Eventually, the economical possibilities granted by her social status allow Pucci to be a seemingly avid consumer of mass culture, while the prohibitive costs of traveling, cinema tickets, books, novels and illustrated journals prevented the majority of Italian girls to enjoy them (de Grazia 1992, 132).

\footnotetext{
${ }^{3}$ Luigi Freddi was president of the Ministry of Popular Culture's Division for Cinema (direzione generale per il cinema), an institution that had the specific purpose of supervising and administering the overall cinema production of Italy. In his leadership and his vision for the Division, Freddi had been originally inspired by a trip to Hollywood during which, for eight weeks, he reportedly '[...] snooped around everywhere, with the only concern of watching and learning in a city ripe with seductions.'

${ }^{4}$ Mario Camerini in Sergio Gmerk Germani, 'Conversazione con Mario Camerini', Camerini/De Sica (1975-1978; Rome: Ripley’s Home Video, 2009), DVD.
} 


\section{Grandi Magazzini (1939)}

Whereas a few preliminary varieties of department stores existed in large Italian cities since the second half of the nineteenth century, they were largely unknown to the majority of the population, who had largely been accustomed to buy from small family-run retail stores and artisan laboratories. In Milan, La Rinascente was the very first department store, whose origins dated back to 1865. It was aimed at customers from the upper and upper-middle classes (Zamagni 2003, 402). The department store in I Grandi Magazzini is then a faithful representation of a modern cathedral of consumption, modeled on the real La Rinascente in Milan (Reich and Garofalo 2002, 289). In the film, the chief of staff of I Grandi Magazzini, Bertini, is stealing from the department store with the help of his accomplices, salesgirl Anna and her brother Pietro, a delivery man. Bertini is also infatuated with salesgirl Lauretta, who is courted by delivery man Bruno (Vittorio De Sica). When Bruno accidentally uncovers Bertini's scheme, Anna attempts to seduce Bruno and invites him on a ski trip. Out of jealousy, Lauretta steals a ski suit at the department store to go meet Bruno on the slopes. When Bertini finds out about it, he blames Lauretta for all the thefts incurred at the department store, in order to cover up for himself. Eventually Bruno will figure out the whole plot, have Bertini arrested, and reunite with Lauretta.

The men and women of I Grandi Magazzini are part of that stream of people from all walks of life who fills up the modern cities. Their social condition is nevertheless low, if compared to that of the customers of the department store, but their occupation allows them to come across the exciting novelty brought by both urbanization and advancements in production and marketing of goods. The diffusion of such models of consumption regarded only major Italian cities though, such as Milan, Turin and Rome. The availability of imported prêt-à-porter clothing, make-up and accessories, but also household items and home décor, increased the desirability of the major cities in the eyes of the female population, who was a specific target of the new mass culture of consumption (Reich 1998, 197).

Aware of this aspect, one of the film's producer, Giuseppe Amato, and costume designer Marcello Caracciolo di Laurino established agreements with several Italian brands, in order to regulate the product placement of different sorts of goods. ${ }^{5}$ In a scene when Bruno learns from Bertini that Lauretta is accused of stealing, the camera focuses on a box of 'high quality stockings' branded SiSi. Not all of them were Italian brands, though, as the film featured an Elizabeth Arden booth in the cosmetic division of the store's setting. On the one hand, the regime officially discouraged women to buy make-up, whose use was ascribable to the despicable figure of the flapper, la maschietta as it was called in Italy, and her decadent lifestyle. Perfumes, a market field dominated by French manufacturers, were also the target of Fascist moralists, who instead advised Italian women to prefer, if necessary, cheaper domestic substitutes (Aspesi 1982, 143-7). The female protagonist Lauretta, on the other hand, is always wearing a bright and perfectly applied make-up, paired with manicured nails and in an intense shade of nail polish. Notwithstanding the official warnings, in fact, analyses of the national press of the late 1930s highlight a constant flow of

\footnotetext{
${ }^{5}$ Mario Camerini in Sergio Gmerk Germani, 'Conversazione con Mario Camerini', Camerini/De Sica (1975-1978; Rome: Ripley’s Home Video, 2009), DVD.
} 
lamentations towards the use of make-up and perfumes. As pointed out by journalist Natalia Aspesi, at the time ' $[\ldots]$ nothing seems to stop the offensive feminine frivolity: during Fascism, during the war, and even if ardent patriots, women are resolute in their disobedience when it comes to wear make-up and follow fashion' (Aspesi 1982, 146).

As discussed by film scholar Jacqueline Reich, I Grandi Magazzini spurred consumption in different ways that were not limited to the experience of the film itself (1998). The cineromanzo or cineracconto, which helped the cause of boosting national cinema and spread the success of rising national stars, was one of the ways. ${ }^{6}$ Published as supplements of glossy film magazines, cineromanzi were photoplay editions of films, illustrated with stills and production pictures portraying the actors in the film. The appeal of cineromanzi resided in the quantity of photographs that they included: they could be collected, cut out, posted on walls and therefore enjoyed by the same audience outside the original space of consumption of the cinema theatre. In this way, the experience of the film would go beyond the original space of enjoyment, and persist in the intimacy of one's home. This 'strategy of persistency' was carried out also with the help of frequent references to other successful films. A vivid example is offered by the song Parlami d'amore Mariù, musical theme of the film Gli uomini, che mascalzoni (Cines, 1932), also directed by Mario Camerini and starring Vittorio De Sica. The song, performed by Vittorio De Sica himself, became a huge success both in Italy and abroad (Cardillo 1983, 24). In a couple of scenes from I Grandi Magazzini, Vittorio De Sica/Bruno whistles the theme of Parlami d'amore Mariù, reminding the audience of that previous famous film. In the aims of the regime, the campaign for a national cinema was significantly connected to the campaign for a national fashion discourse, as a collaboration of forces that should act together to spread vivid messages in the collective imagery. Unfortunately, this ambitious project failed because of the scarce cooperation between film industry and national fashion houses, with the lack of influent Italian costume designers who wished to follow the example set by Adrian in the US playing a crucial reason (Monti 2009, 127).

\section{A lifestyle revolution}

The reformation of lifestyle prompted by the regime implied a pedantic campaign for the adoption of a proper Fascist style, planned to invest most aspects of public and private life, from leisure to sport, from language to media, from shopping to fashion (Falasca-Zamponi 1997, 100). ${ }^{7}$ An official style became necessary in order to express the discipline and the orderly fashion in which the dictatorship claimed to have reorganized the nation. For this reason, restructuring fashion and aesthetics was crucial in the establishment of a Fascist style, since the desired institution of a brandnew national lifestyle depended also on a coherent visual identity. In particular, as stated by Eugenia Paulicelli, Fascism understood fashion in particular as ' $[\ldots]$ one of the privileged vehicles with which Italy has sought to create, promote and define a national identity for itself' $(2004,2)$. Indeed, the nationalization of fashion was one of the most crucial goal planned by the dictatorship, an aesthetic crusade conducted by means of diktats on dress code, promotion of the national

\footnotetext{
${ }^{6}$ Combinations of cinema and romanzo, novel (but also 'romantic fiction'), or racconto, short story.

${ }^{7}$ Achille Starace, secretary of the National Fascist Party, was the most strenuous advocate for the adoption of a Fascist aesthetics that would characterize Italian national identity.
} 
manufacturing industry and self-sufficiency. National propaganda increased the advertisements of national products, stressing the need to impose a certain distance against the French dominance in taste for fashion, to instead nurture its own style by means of its own industry and, most important, its own fashion discourse.

Counting on several influent advocates, the regime recognized the cause for a national fashion, which officially took off in 1932 with the establishment of Ente Nazionale della Moda (National Fashion Board) (Gnoli 2000). The board, directly managed by the regime, created a special 'quality seal' to be appointed to those fashion houses that could demonstrate their creations to be nonderivative and authentically Italian, in both design and production. The ENM celebrated national producers of clothing and accessories, publicized domestic traditions of craftsmanship, and pleaded Italian women, especially the wealthier ones, to prefer national fashion to foreign imports (Paulicelli 2004, 21). It was a perfect timing to boost domestic lifestyle productions then, since it was precisely in the 1930s that fashion 'transcended class lines' and women and men from different social strata could follow the same trends, expanding their aspirations for a modern lifestyle (de Grazia 1992, 221).

\section{The language of fashion}

The Italianization of foreign words was an important part of the cultural politics of Fascism. The reform of the language was explicitly part of the project for a national Fascist style promoted by the regime, and invaded different linguistic aspects of both public and private life. The reliance on the capillarity of its mass media helped the regime in promoting different campaigns for the cleanliness and integrity of the language. The use of foreign words was unanimously condemned as a threat to the purity of Italian language who led consumers to familiarize with non-Italian terms. Eventually, in 1940, a national law compelled manufacturers to write scrupulous comprehensive descriptions in Italian, with Italian terms, for those products that originally employed foreign names or expressions. This became valid for every possible class of advertising activity, from packaging to billboards to radio ads (Foresti 2003, 60).

Linked to the linguistic propaganda, the campaign for the nationalization of the fashion discourse tried to reach its height with the creation of a specific commentary-dictionary of fashion, commissioned by ENM to fashion journalist Cesare Meano in 1936 (Paulicelli 2004, 57). The text specifically listed all the most important entries connected to fashion, leisure and lifestyle, yet attempts of purging the commonly used lexicon from foreign loans in French and in English were quite rare. In this sense the project of the dictionary can be seen as an attempt to restore the prestige of Italian fashion, both nationally and internationally, and therefore to 'create the culture for an appreciation of Italian taste and fashion both at home and abroad' (Paulicelli 2009, 282). This is a concept that specifically highlights the need for a national discourse in the broader perspective of international fashion capitals.

While the regime condemned the use of foreign words, everyday language was hardly just 'purely' Italian, as it is represented in both Il signor Max and I I Grandi Magazzini. 'Censored' terms seemingly sounded less familiar than foreign loans themselves. In Il signor Max, for instance, 
Gianni repeatedly, though reluctantly, drinks 'whiskies', and does not use the purged Italian equivalents acquavite or spirito d'avena (oat alcohol). When taking lessons in different sports, he starts practicing tennis, but never refers to it with the suggested Fascist name of pallacorda (ballrope). During the dancing night aboard the ship, when he has the first conversation with Paola, Gianni is gifted with French cotillions, as nobody ever pronounces the preposterous Italian translation cotiglioni.

In I Grandi Magazzini, Lauretta suggests a friend to spend her extra money to buy ' $u n$ bel tailleur' (a suit with blazer), instead of a utilitarian 'paletot pesante', a thick winter coat. It is interesting to note that Lauretta uses the French word tailleur and not a 'completo a giacca', which was the version officially suggested by Meano, and that she could have said cappotto, the Italian word for coat (Gnoli 2005, 78).

When examining the translation proposed by the regime one notices a certain lack of creativity. Most of the substitutions consisted in fact of phono-semantic matchings of French loanwords, as in the case of the French words chignon, describing a hairstyle, transformed into cignone in Italian, and couturier, which becomes cucitore (Aspesi 1982, 94). Linguists and journalists were asked to spend their efforts in adapting the originals into acceptable Italian equivalents, but their endeavor could not produce anything more than scarce onomatopoetic adaptations. The Italianization of words related to fashion and lifestyle was another pedantic but unsuccessful intervention of the regime, which failed because of the different cultural forces that interplayed at the time, as suggested by Gundle and David Forgacs (2007, 2-3).

\section{Conclusion}

The political reticence that accompanied Italian historiography for quite a long time delayed the opportunity to analyze the Fascist ventennio of 1922-1943 free from ideological preconceptions. In particular, the film productions of this period had been unanimously dismissed for a long time, largely on the presumption of their overall inferiority in technical, narrative and aesthetic aspects, especially if compared with postwar neorealism. The negative opinions that critics and film scholars directed at the so-called genre of telefoni bianchi would come to encompass the whole film production of Italy during Fascism, de facto agreeing with philosopher Benedetto Croce's interpretation of Fascism as an anomaly, an irregularity in the history of Italy, a 'contemporary sickness from which Italy was the first to suffer' $(1943,45)$. On the other hand, the romantic comedies of Mario Camerini represent the insight that Landy suggests to look for when reassessing this crucial period of Italian cultural history (Landy 1986, 20). Camerini showed a predisposition to realism and an interest for the vicissitudes of the working class, in opposition to the ostentatious escapism of the 'proper' telefoni bianchi genre or the bombastic celebrations of Fascism of the (few indeed) propagandist films. By looking at them as representations of the society of the time, the two films Il signor Max and I Grandi Magazzini are capable of highlighting the innate contradictions of Fascism and its attempts in constructing a new 'Fascist' lifestyle in fashion and culture. In these two films, Camerini was able to condense consistent references to the cultural debate of Italian society of the late 1930s: the rejection of Parisian and Anglo-American references in apparel and luxury goods, the quest for a national image of Italian fashion and the attempts to promote the Italian film 
production with intertextual references like the cineromanzo. Overall, the two films are a reminder of the attempts of Fascism to establish a consistent national discourse in both fashion and film production. These attempts to the formation of a 'new' national identity, though, were contrasted on different levels by 'a complex network of negotiations, concessions and compromises, as well as various, often tacit, forms of opposition, noncompliance, and resistance' (Forgacs and Gundle 2007, 3), which can be already discerned in the two films.

\section{References}

Aspesi, N. (1982) II Lusso \& L'autarchia: Storia Dell'eleganza Italiana, 1930-1944. Milano: Rizzoli.

Cannistraro, P.V. (1975) La fabbrica del consenso, Bari: Laterza

Cardillo, M. (1983) II Duce in Moviola: Politica E Divismo Nei Cinegiornali E documentari "Luce." Bari: Edizioni Dedalo

Casadio, G., Laura, E.G. and Cristiano, F., eds. (1991) Telefoni Bianchi. Realtà E Finzione Nella Società E Nel Cinema Italiano Degli Anni Quaranta. Ravenna: Longo

Celli, C. (2001) 'The Legacy of Mario Camerini in Vittorio De Sica' S The Bicycle Thief (1948)'. Cinema Journal 40, no. 4, 3-17

Croce, B. (1943) 'The Fascist Germ Still Lives'. New York Times, November 28, 9, 44-45

de Grazia, V. (1992) How Fascism Ruled Women : Italy, 1922-1945. Berkeley: Univ. of California Press

. (1981) The Culture of Consent. Mass Organization of Leisure in Fascist Italy. Cambridge: Cambridge University Press

Falasca-Zamponi, S. (1997) Fascist Spectacle: The Aesthetics of Power in Mussolini's Italy. Berkeley: University of California Press

Foresti, F., ed. (2003) Credere, Obbedire, Combattere. I/ Regime Linguistico Nel Ventennio. Bologna: Pendragon

Forgacs, D., and Gundle, S. (2007) Mass Culture and Italian Society from Fascism to the Cold War. Indiana University Press

Gentile, E. (2003) I/ Culto Del Littorio: La Sacralizzazione Della Politica nell'Italia Fascista. 2nd ed. Bari: Laterza

Gnoli, S. (2000) La Donna, L'eleganza, II Fascismo: La Moda Italiana Dalle Origini all'Ente Nazionale Della Moda. Catania: Edizioni del Prisma

—_. (2005) Un Secolo Di Moda Italiana, 1900-2000. Roma: Meltemi Editore srl

Gundle, S. (2013) Mussolini's Dream Factory: Film Stardom in Fascist Italy. New York: Berghahn Books

Landy, M. (1986) Fascism in Film : The Italian Commercial Cinema, 1931-1943. Princeton: 
Princeton University Press

. (1998) The Folklore of Consensus: Thetricality in the Italian Cinema, 1930-1943. Albany: SUNY Press

Monti, G. (2009) 'Italian Divas', in Lupano, M, and Vaccari, A., eds. (2009) Fashion at the Time of Fascism: Italian Modernist Lifestyle 1922-1943. Bologna: Damiani Editore, p. 127

Mida, M., and Quaglietti, L. (1980) Dai Telefoni Bianchi Al Neorealismo. Bari: Laterza.

Moliterno, G. (2008) Historical Dictionary of Italian Cinema. Plymouth: Scarecrow Press, Inc.

Paulicelli, E. (2004) Fashion under Fascism : Beyond the Black Shirt. Dress, Body, Culture. Oxford: Berg

- (2009) 'The nationalization of the language' in Lupano, M, and Vaccari, A., eds. (2009) Fashion at the Time of Fascism: Italian Modernist Lifestyle 1922-1943. Bologna: Damiani Editore

Pugliese, S., ed. (2001) Italian Fascism and Antifascism: A Critical Anthology, ed. Stanislao Pugliese. Manchester: Manchester University Press

Reich, J. (1998) 'Consuming Ideologies: Fascism , Commodification , and Female Subjectivity in Mario Camerini's Grandi Magazzini'. Annali d'Italianistica 1, January, 195-212

Reich, J., and Garofalo, P. eds. (2002) Re-Viewing Fascism : Italian Cinema, 1922-1943. Bloomington: Indiana University Press

Zamagni, V. (2003) Dalla Periferia Al Centro: La Seconda Rinascita Economica dell'Italia (1861-1990). Bologna: II Mulino

\section{Biography}

Chiara Faggella is a Ph.D. candidate at the Department of Media Studies at Stockholm University, Sweden. She holds an MA in Fashion Studies from Stockholm University and graduated summa cum laude from Università degli Studi di Pisa with a BA in Communication Studies. Her soon-to-be discussed doctoral thesis is a historical project on the postwar promotion of Italian fashion for export in the international market. Chiara's additional research interests include oral histories of postwar Italian dressmakers and their consumers; history of costume departments of the interwar Italian film industry; and the developments of trade agencies for the promotion of Italian fashion merchandise.

E-mail: chiara.faggella@ims.su.se 